\title{
Kaza ve Olay Araştırmalarına Dayalı Demiryolu Emniyet Yetkinlikleri Geliştirilmesi: Kök Neden Taksonomilerini Kullanarak Kazalardan Öğrenmek
}

\author{
Developing Rail Safety Competencies Based on Accident and Incident Investigations: \\ Using Root Cause Taxonomies to Learn from Accidents
}

\author{
Ibrahim Müjdat BAŞARAN, Sinan YILMAZ
}

\begin{abstract}
ÖZET
Bilgi çağında; bilginin örgütsel başarının temel belirleyici faktörlerinden biri haline gelmesi ile birlikte, "Örgütsel Emniyet" kavramı da giderek bilgi yönetim sistemlerine daha bağımlı hale gelmektedir. Bir yönetim süreci olarak Bilgi Yönetimi, örgütsel bilginin elde edilmesi, geliştirilmesi, paylaşılması ve etkin biçimde kullanılması ile ilgili faaliyetleri kapsar. Örgütsel etkinliğin sağlanabilmesi için bilgi yönetimi yaklaşımları, örgütsel hafıza ve örgütsel öğrenme sistemleri birbiriyle etkileşim halindedir. Bu çalışmada kaza ve olay araştırma yaklaşımlarını ve "Emniyet Yönetimi" kavramını "Örgütsel Emniyet Stratejileri", "Örgütsel Emniyet Yetkinlikleri" ve "Bilgi Yönetim Sistemleri" açısından yazında mevcut araştırmalar ışığında inceledik.

Anahtar Kelimeler: Kaza Nedensellik Teorileri, Emniyet Yetkinlikleri, Kök Neden Taksonomileri, Bilgi Yönetimi

ABSTRACT

In the knowledge age, as knowledge becomes the main determinant of organizational success, organizational safety becomes increasingly dependent on knowledge management systems. As a management process, Knowledge Management includes capturing, developing, sharing and effectively using organizational knowledge. For organizational effectiveness, approaches of knowledge management, systems of organizational memory and organizational learning systems interact with each other. In this study, we examine Accident and Incident Investigation Approaches and the concept of Safety Management in terms of "Organizational Safety Strategies", "Competencies for Organizational Safety" and "Knowledge Management Systems", in light of extant research.
\end{abstract}

Keywords: Accident Causation Theories, Safety Competencies, Root Cause Taxonomies, Knowledge Management

\footnotetext{
Yrd. Doç. Dr. İbrahim Müjdat BAŞARAN - Bülent Ecevit Üniversitesi, İktisadi ve İdari Bilimler Fakültesi, Zonguldak, Türkiye

Assist. Prof. Ibrahim Mujdat BASARAN - Bulent Ecevit University, Faculty of Economic \& Administrative Sciences, Zonguldak, Turkey

imbasaran@beun.edu.tr

Yrd. Doç. Dr. Sinan YILMAZ - Bülent Ecevit Üniversitesi, İktisadi ve İdari Bilimler Fakültesi, Zonguldak, Türkiye

Assist. Prof. Sinan YILMAZ - Bulent Ecevit University, Faculty of Economic \& Administrative Sciences, Zonguldak, Turkey

syilmaz@beun.edu.tr

*This paper has been published in Proceedings of 2016 IEEE International Conference on Industrial Engineering and Engineering Management.
} 


\section{INTRODUCTION}

Web of complicated systems, which affect industrial organizations, causes different types of risks to coexist [1]. As the global demand for transportation grows and expectations of customers rise, in terms of both speed and quality, railway systems transform into one of the riskiest domains for both workers' and public safety [2-4]. On the other hand, in addition to national and international directives, regulations and standards; the concepts of risk analysis and accident investigation start to play an everincreasing role in individual and organizational learning.

Safety is a key business objective of any transportation system. As a result, the rail industry, which is undergoing a dynamic growth, is experiencing development of many new technologies designed to improve industrial safety. To fully realize the benefits of such technologies, adopting a proper safety approach and development of safety competencies are essential requirements. Railway organizations and governments invest in different types of technologies in order to create efficient, effective, safe and interoperable railway systems. On the other hand, expensive technological investments and restructuring of railway organizations don't necessarily guarantee the operational safety of railway systems.

According to Checkland [5], organizational structures reflect systems thinking and consist of three different components: (1) organizational units, (2) relations between organizational units, and (3) relations as a whole that constitute one unit. From a systems perspective, organizations consist of hard components at one end and soft components at the other [6]. In addition, according to Wilson and Norris [7] railway networks consist of highly critical hard components such as railway lines, signaling \& communication facilities, traffic management systems, rolling stock, organizational staff, different types of departments, teams and third party service providers etc. Despite a general acknowledgement regarding complexities of operational processes and difficulties in working conditions of railway systems accident and incident investigations in railway systems mainly focus solely on unsafe actions of workers or equipment defects.

On the other hand; unlike traditional approaches, which concentrates on the errors of organizational staff, accusing them for inattentive behaviors or unsafe actions; the systems approach focuses on the conditions under which individual's work and builds countermeasures to avert technical, organizational and staff based errors. The main assumption of this approach is the impossibility of controlling human factor and the main focus is on changing latent conditions which determine workers' work.
Accident investigations are important data sources for organizational learning. However, absence of ontological foundations raises questions regarding reliability of conclusions. Since unreliability becomes a major barrier for quantifiability, knowledge management based safety systems becomes untenable.

Building a knowledge management based safety management system requires an ontologically sound taxonomy for causal relations that are also able to take into consideration hierarchic order of causalities attributed to adverse events.

In this paper, we discuss accident causation theories and knowledge-based strategies for the creation of safety competencies.

\section{ACCIDENT CAUSATION THEORIES}

Traditionally, railway industries take a reactive approach to industrial safety. Accordingly, safety priorities come into prominence only when there is a sensational accident that results in deaths or serious financial burden. On the other hand, the fundamental aim of a safety system is the minimization of risks through a proactive approach. A proactive safety approach entails eliminating risks before an incident or accident occurs. Transformation of safety strategies from reactive to proactive requires precautions to be taken for as many hazards as possible. Accidents are main data sources for proactive improvement strategies and accident causation theories determines the paradigm of investigators and decision makers.

According to Albert and others [8], the focus of early accident causation models was predominantly on modeling of behavior and personal characteristics of workers as the primary causes of accidents. These models assert that certain individuals have a natural tendency to err and are more likely to be involved in accidents [9]. On the other hand, according to Kerr [10], people fundamentally differ in their innate propensity for accidents and this propensity comes from the resistance of some workers to change.

Domino Theory is generally accepted as the first accident causation model. According to this model [11], linear causal chains result in adverse events. These causal chains can be triggered by personal errors, social environmental conditions, and unsafe work behaviors.

Following one-dimensional linear models, James Reason who was inspired by Systems Theory introduced multidimensional causality models. According to Reason [12], accident causation depends on the interaction between system components and this interaction has a non-linear nature. Therefore, based on a systemic approach, main 
responsibility of investigators should be the exploration of the nature of interactions between sub-systems. According to this approach accidents are the results of interactions between interdependent parts of systems $[10,13]$.

Another suggestion of the Reason's model concerns different types of failure. Systems approach brings a different perspective to human error. According to this view, systems are analyzed as whole entities, rather than isolated components [14]. The basic assumption of the systems approach is that humans are liable to make mistake or cause errors and even the best organization must be prepared for those errors. Errors are seen as causes rather than consequences and by their nature are affected by systemic factors such as technical faults, faulty work orders or ineffective organizational processes. The systems approach, therefore, concentrates on adverse conditions and builds countermeasures to prevent errors or to mitigate their effects. In an ideal world, these layers provide a safeguard that will prevent a certain combination of events potentially resulting with an undesired consequence. However, in reality, these layers have active and latent holes. As can be seen in Figure 1, Reason explained [12] this concept through a metaphor.

According to this way of thinking, the presence of holes in one layer can be compensated with other layers but sometimes all the holes could line up and an accident becomes inevitable. The holes in the defensive layers arise due to two reasons: (1) active failures, (2) latent conditions. Almost all adverse events ensue as a result of interaction between two sets of factors: Active failures are the results of unsafe actions of people who are in direct contact with the system whereas; latent conditions are the dormant characteristics of the system such as technical or organizational weaknesses [12].

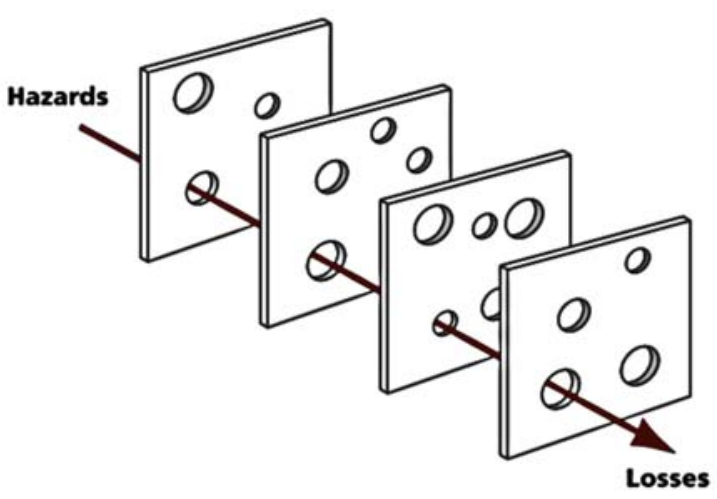

Fig 1: Swiss cheese model, which shows the operation of defensive layers in order to prevent accidents [12].

According to the research $[3,4,15-17]$ over the last two decades, human factor considerations in advanced technological systems have become increasingly important and there is not so much doubt about the effects of human error to the majority of railway accidents and incidents. Traditional safety analyses have tended to address safety by focusing mainly on technical aspects and investigating the immediate causes of accidents and incidents [18]. On the other hand, the growth in global railway transportation demand and recent accidents make it necessary to develop proactive and efficient strategies to assure railway safety. In addition to the necessity of proactive approaches the emergence of new regulations and international standards are motivating organizations to increase system safety [19-21].

\section{CREATION OF SAFETY COMPETENCIES}

According to Möller and others [22] there are two wellestablished alternative views on where the term "Safe" should be placed on the scale. According to one view, "safe" denotes the top end of the scale where the risk is zero. The other view posits "safe" to be a relative concept explicable as "with a reasonable degree of safety".

In highly complex industrial systems such as railway transportation, resources are scarce and their allocation is essential. Therefore, in the later perspective, quantified risk assessment and management models replace traditional subjective risk evaluation methods. According to this view, risk-based techniques provide qualitative and quantitative measures for decision makers based on priorities. In this context, accident and incident investigations provide critical data about risk levels, safety priorities and learning requirements of organizational systems.

Risk assessment models consider two basic criteria of "probability of occurrence" and "extent of damage" [23]. Risk assessment is thus based on facts, which can be estimated by means of extrapolating past observational data and experience. On the other hand, fact based risk characteristics of systems cannot be considered in isolation from the technical, staff related and managerial circumstances of its operation [12].

In the knowledge age, knowledge is the main determinant of economic progress and; with their abilities to continuously develop new competencies, learning organizations are the idealized organization type. According to Abel [24], organizations face two risks: (1) knowledge obsolescence with respect to their technological and competitive environment and (2) loss of competencies. These two kinds of risks push organizations to change their paradigms about knowledge management. Therefore, main responsibilities of implementations of knowledge management are 
to change the stock logic about knowledge and continuously develop new competencies.

The concept of "competence" can be described as putting into practice some knowledge in a specific context [24]. According to Klass [25], competence is a contextdependent concept due to its nature, which combines the abilities of working staff, the ecology of working environment and working conditions. Accordingly, safety competencies can only be assessed in working places [26] and data collection, the transformation of data into information and knowledge, formatting, storing and leveraging of knowledge become main duties of complex industrial organizations.

Learning activity is the outcome of complex processes and the success of these processes depends on both humans and organizations. Knowledge-based organizational structures, unlike traditional ones, generally work with small units called as "communities of practice".

\section{Impact to Organizational Effectiveness}

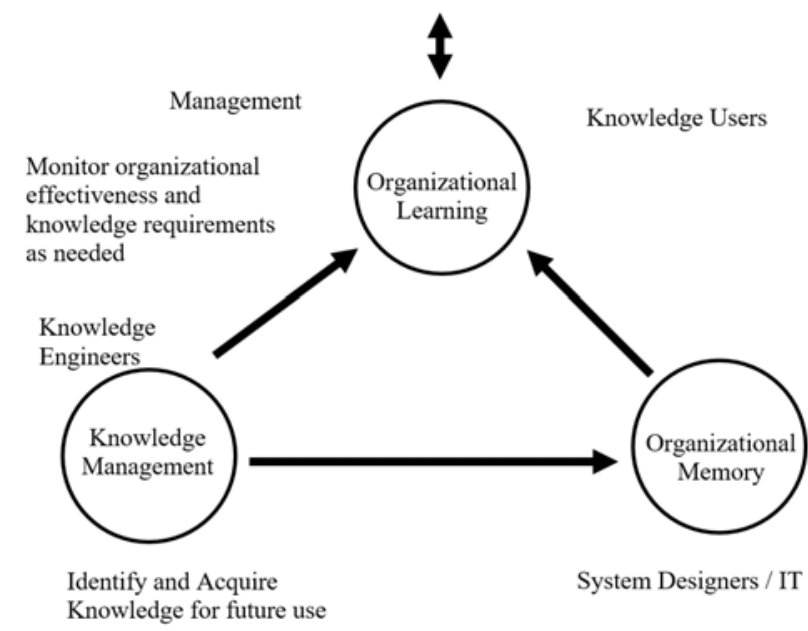

Fig. 2: Knowledge management, Organizational memory, and organizational learning model [28].

According to King [27], the most fundamental taxonomy that specifies different kinds of knowledge is "tacit knowledge" and "explicit knowledge". While tacit knowledge is cognitive and embedded in business processes, explicit knowledge is organized and documented. One of the main responsibilities of knowledge management is transforming tacit knowledge into explicit knowledge, hence making it available for organizational dissemination.

According to Jennex [28], organizational effectiveness depends on the interaction between three system components: (1) knowledge management systems, (2) organizational memory, and (3) organizational learning. From this point of view, knowledge management systems identify knowledge artifacts and establish key processes for capturing this knowledge. Organizational memory refers to IT infrastructure for storing, indexing, searching and retrieving knowledge artifacts and organizational learning is the main outcome, which is, realized when users internalize knowledge and change their behaviors as desired.

The railway industry has been searching for different kinds of solutions to railway safety since the first railway accident. However, during the last decades, the term of "safety management system" has attained a central status for both railway transportation along with other industrial areas. As a new and emerging discipline, Rail Safety Management Systems provide new insights on how to drastically improve risk management and rail safety. A safety management system contains all the items used in managing safety. These include all of; the people, the procedures, the hardware and the software that is deployed within the system and have an effect on the level of the safety of the system. According to Ming [29], a Safety Management System could be defined as the combination of policies, objectives, organization, different types of management control techniques and resources, which are in place to manage safety in all parts of the organization.

There are different safety roles and responsibilities across all levels of organizations. According to Crutchfield and Roughton [30] as comprehensive management systems designed to manage safety elements, responsibilities of safety managements systems come into prominence to involve accomplishment of the following elements: (1) to ensure everyone in the organization can recognize and understand real or potential hazards and associated risk, (2) to prevent or control operational hazards and associated risk, (3) and to train employees at all levels of the organization so they can demonstrate the impor-tance of correcting potential hazards they may be routinely exposed to as well as how to protect themselves and others.

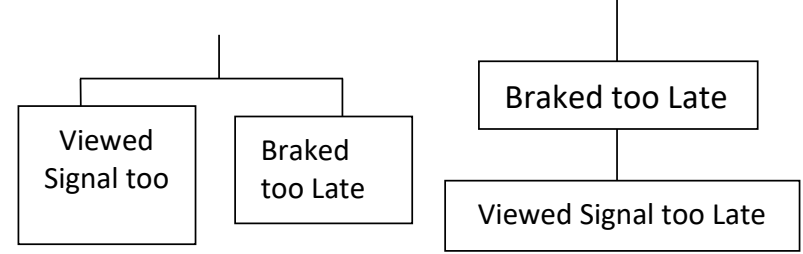

Fig. 3: Traditional root cause analysis and root cause analysis which considers the interaction of root causes. [6]

Accident and incident analysis are essential data sources for organizational learning and development of safety competencies based on continuous process improvement. Ac- 
cording to van der Schaaf \& Wright [31] root cause taxonomies allow an organization to rise above the traditional qualitative mechanisms of learning at the single accident level owing to common ontological foundations of root causes which used by every single investigator.

At the same time, root cause taxonomies allow investigators to objectively show different causal interactions of different types of root causes. As we mentioned previously, usage of same ontological basis by different investigators provides quantitative analysis opportunities. On the other hand, traditional fault tree analysis does not consider a causal hierarchy between different root causes. Figure 3 illustrates the two different approaches suggested by Dabekaussen and others [32]. The example here relates to an incident where a train driver brakes too late. The approach on left does not consider a causal hierarchy and attributes the incident to train driver viewing the signal too late, and braking too late. Whereas, the approach on the right takes into consideration causal hierarchy between root causes and attributes braking too late because of viewing the signal too late. In other words without causal hierarchy the incident was caused by the driver viewing the signal too late and braking too late, whereas with causal hierarchy braking too late is a consequence of viewing the signal too late.

We can better illustrate practical implications of the different types of causal approaches in the context of an example. As we can see in the figure 4, the traditional analysis of 100 hypothetical accidents would result in 100 root causes being identified.

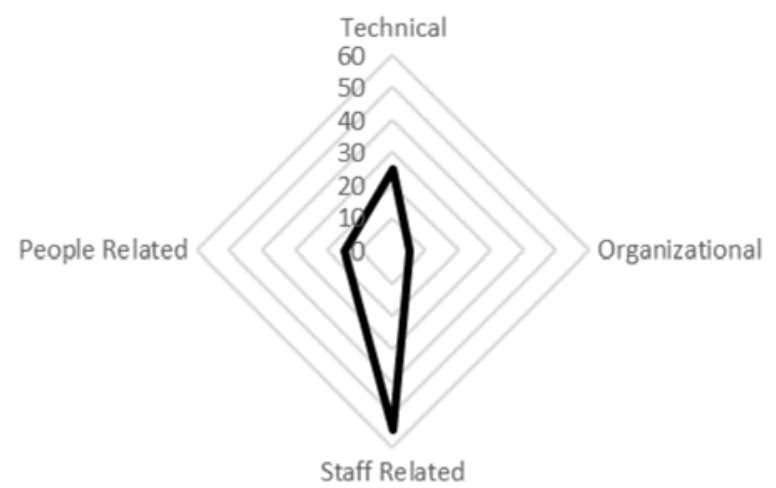

Fig. 4: Traditional analysis of 100 hypothetical accident

In figure 5, we illustrate results of non-hierarchic root cause analysis in which interactions aren't taken into consideration.
While traditional accident analysis suggests one cause for each accident, root cause analysis considers multiple root causes. On the other hand, absence of a root cause taxonomy means reliability problems. Since without taxonomies, different investigators extrapolate different causal interactions based on same accidents but different ontological assumptions.

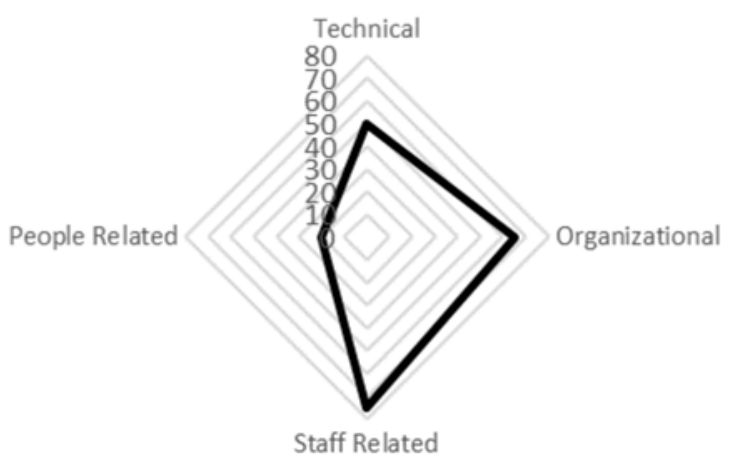

Fig. 5: Root cause analysis of 100 hypothetical accident

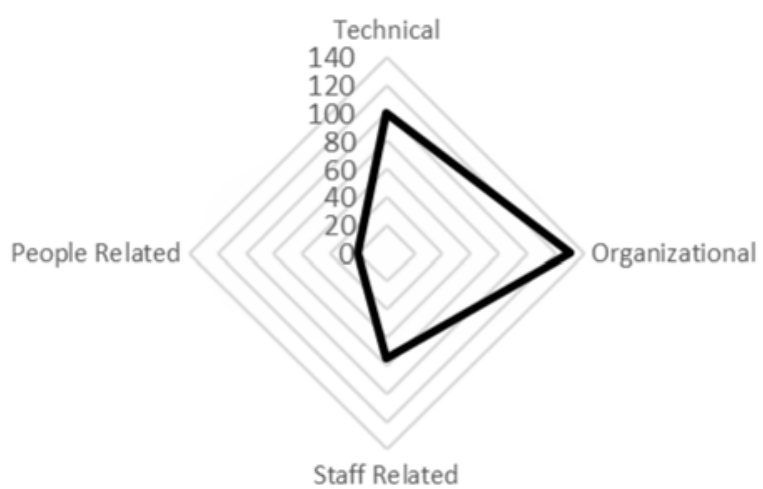

Fig. 6: Hierarchic root cause analysis based on root cause taxonomies consider the interaction of root causes

As can be seen in figure 6, hierarchic root cause analysis with root cause taxonomies provide reliable, quantitative and interaction based information about accidents, which is also one of the most critical feature necessary knowledge management based safety management implementation. 


\section{CONCLUSIONS}

Rail safety management systems have evolved over the last two decades, as soft components of railway organizations. Development of safety competencies in complex systems like railways, necessitate translating tacit knowledge into explicit knowledge. One of the most important resources where tacit knowledge in rail systems can be uncovered is accident investigations.

Although different approaches to accident investigations exist, the selected approach determines the quality of knowledge to be uncovered. The basic premise of the systems approach, which can be summarized as human are fallible and errors, must be expected, and systems safety is affected by interaction of different causes.

Accident analysis is a key component of organizational learning. To this purpose, root cause taxonomies enable an ontological base, provide quantitative analyzing opportunities and allow for an overview of relative frequencies of full range of causes in a database of large numbers of accidents for identification of their dominant failure patterns. The resulting recommendations for failure prevention should allow managers to take effective and efficient action to increase the safety and other performance indicators of their organization.

\section{REFERENCES}

[1] C. A. Ericson, Hazard Analysis Techniques for System Safety. New Jersey: John Wiley \& Sons, 2005, pp. 112.

[2] J. R. Wilson, and B. J. Norris "Rail human factors: past, present and future," Applied Ergonomics, vol. 36, no. 6, pp. 649-660, Nov. 2005.

[3] M. T. E. Baysari, S. M. Andrew, and J. R. Wilson "Understanding the human factors contribution to railway accidents and incidents in Australia," Accident Analysis and Prevention, vol. 40, no. 5, pp.1750-1757, Sep. 2008.

[4] S. Hall, Beyond Hidden Dangers: Railway Safety into the 21st Century. Surrey: Ian Allan Publishing, 2003, pp. 1-17.

[5] P. Checkland, "Systems theory and management thinking," American Behavioral Scientist, vol. 38, no. 1, pp. 75-91, Sep. 1994.

[6] C. L. Wang, and P. K. Ahmed, "Structure and structural dimensions for knowledge-based organizations," Measuring Business Excellence, vol. 7, no. 1, Jan. 2003.

[7] J. R. Wilson, and B. J. Norris, "Rail human factors: past, present and future," in Rail Human Factors: Sup- porting the Integrated Railway, J. R. Wilson, B. J. Norris, T. Clarke, A. Mills, Ed. Burlington: Ashgate Publishing, 2005, ch. 1, pp.3-12.

[8] A. Albert, M. R. Hallowel, and B. M. Kleiner, "Emerging strategies for construction safety \& health hazard recognition," Journal of Safety, Health \& Environmental Research,, vol. 10, no.2, pp.152-161, Mar. 2014.

[9] L. Shaw, and H. S. Sichel, Accident Proneness: Research in the Occurance, Causation and Prevention of Road Accidents. New York, NY: McGraw-Hill, 1971, pp. 11 $-27$.

[10]P. M. Salmon, M. Cornelissen, and M. J. Trotter, "System based accident analysis methods: a comparison of accimap, hfacs and stamp analysis," Safety Science, vol. 50, no.4, pp. 3-9, 1158-1170, Apr. 2013.

[11]P. G. P. Sabet, H. Aadal, M. H. M. Jamshidi, and K. G. Rad, "Application of domino theory to justify and prevent accident occurance in construction sites," IOSR Journal of Mechanical and Civil Engineering, vol. 6, no. 2, Mar. 2013.

[12]J. T. Reason, "Human error: models and management," British Medical Journal, vol. 320, pp.768-770, Mar. 2000.

[13]N. A. Stanton, L. A. Rafferty, and L. A. Blane, "Human factors analysis of accidents in system of systems," Journal of Battlefield Technology, vol. 15, no.2, pp. 23-30, Jun. 2012.

[14]P. Underwood, and P. Waterson, "Systemic accident analysis: examining the gap between research and practice," Accident \& Prevention, vol. 55, pp. 154-164, Jun. 2013.

[15]P. C. Cacciabue, "Human error risk management methodology for safety audit of a large railway organization," Applied Ergonomics, vol. 36, no. 6, pp. 709718, Nov. 2005.

[16]A. Pasquini, A. Rizzo, and L. Save, "A methodology for the analysis of spad," Safety Science, vol. 42, no. 5, pp. 437-455, Jun. 2004.

[17]H. Iridiastadi, and Z. F. Ikatrinasari, "Indonesian railway accidents: utilizing human factor analysis and classification system in determining potential contributing factors," Work: A Journal of Prevention Assessment and Rehabilitation, vol. 41, pp. 4246-4249, 2012.

[18]J. Santos-Reyes, and A. N. Beard, "Assessing safety management systems," Journal of Loss Prevention in the Process Industries, vol. 15, no. 2, pp.77-95, Mar. 2002.

[19] V. M. Sutherland, P. Makin, and C. Cox, Management of Safety: The Behavioral Approach to Changing 
Organizations, London: Sage Publications, 2000, pp. 3 $-27$.

[20] F. K. Crawley, "The change in safety management for offshore oil and gas production systems," Process Safety and Environmental Protection, vol. 77, no. 3, pp. 143148, May 1999.

[21] F. A. Manuele, Advanced Safety Management: Focusing on Z10 and Serious Injury Prevention. New Jersey: Wiley, 2008, pp. 7-33.

[22] N. Möller, S. O. Hansson, and M. Peterson, "Safety is more than the antonym of risk," Journal of Applied Philosophy, vol. 23, no.4, Nov. 2006, pp. 419-432.

[23] J. Reason, Managing the risks of organizational accidents. Vermont: Ashgate Publishing, 1997, pp. 1-20.

[24] M. H. Abel, "Competencies management and learning organizational memory," Academic Medicine, vol. 82, no. 6, Nov. 2008, pp. 15-30.

[25] D. Klass, "A performance-based conception of competence is changing the regulation of physicians' professional behavior," Journal Knowledge Management, vol. 12, no.6, Nov. 2008, pp. 529-535.

[26] A. Okuyama, K. Martowirono, and B. Bijnen, "Assessing the patient safety competencies of healthcare professionals: a systematic review," $B M J$ Quality \& Safety, Acc. 21, Jul. 2011, pp. 1-10.

[27] W. R. King, "Knowledge management and organizational learning," in Knowledge management and organizational learning: Annals of Information Systems, W. R. King, Ed. Springer, New York, 2009, ch. 1, pp. 313.

[28]M. Jennex, Case Studies in Knowledge Management. Hershey: IDEA Group Publishing, 2005, pp. 8.

[29]K. T. Ming, "Application of a quality management system approach to health, safety and environment. in offshore South East Asia," in Proceedings of the 10th Conference and Exhibition World Trade Centre, Singapore, Dec. 1994, pp. 739-745.

[30]J. Roughton, and N. Crutchfield, Safety Culture: An Innovative Leadership Approach. Oxford: Elsevier, 2014, pp. 3-21.

[31] T. W. van der Schaaf, and L. B. Wright, "A Generic Root Cause Analysis Approach for the Railway Industry," in Rail Human Factors: Supporting the Integrated Railway, J. R. Wilson, B. J. Norris, T. Clarke, A. Mills, Ed. Burlington: Ashgate Publishing, 2005, ch. 11, pp. 413-419.

[32] M. Dabekaussen, T. W. van der Schaaf, and L. B. Wright, "Improving incident analysis in the Dutch railway sector, Safety Science Monitor, vol. 11, no. 2, 2007, pp. 1-10. 
